Schiener, E. J. 1975: Basin study: central West Greenland onshore Cretaceous-Tertiary sediments. IXme Congrés international de Sedimentologie Nice 1975 Theme 5, Tome 2, 379-385.
Surlyk, F. 1982: Kul pả Nûgssuaq, Vestgrønland. In Shekhar, S. C., Frandsen, N. \& Thomsen, E. Coal on Nâgssuaq, West Greenland, 43-56. Copenhagen: Geol. Surv. Greenland.

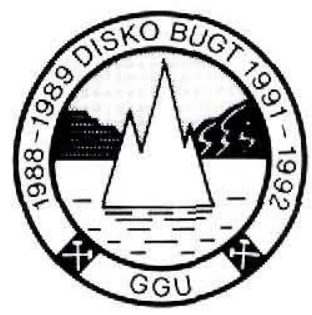

During the 1988 field season coal-bearing strata in the Upper Cretaceous Atane Formation on southern Nûgssuaq, West Greenland (fig. 1) were investigated in order to describe and interpret the sedimentological features. On the basis of this, it was hoped that a more refined synthesis of the regional geology could be made.

Previous work in the area has dealt mainly with the dating of the formation (earlier references in Rosenkrantz, 1970), its assemblage of plant fossils (Heer, 1883; Seward, 1926), marine macrofossils (Steenstrup, 1874; Ravn, 1918) and its coal potential and petrography (Shekhar et al., 1982).

The general depositional environment was discussed by Schiener (1975) and Henderson et al. (1976). The GGU coal project (Shekhar et al., 1982) adopted the models presented in these papers but despite impressive field work did not shed much new light on the origin of these sediments.

The topography at the localities investigated is impressive and typically glacial (fig. 3). Glacier-capped basalts up to a height of $2000 \mathrm{~m}$ overlook relict glacial valleys carved out in lower lying basalts, agglomerates and intercalated sediments of Tertiary age. At a height of 400 to $800 \mathrm{~m}$ a moderate to weak angular unconformity is found, below which the interbedded sand, shale and coal of the Atane Formation outcrop in a number of deeply dissected gullies.

Field work took place from 1st July to 26th August at three main localities: Pautût, Kingigtoq and Atanikerdluk (fig. 1). It was supported by boat and helicopter in connection with other GGU activities in the area (Kalsbeek, 1989). The present paper describes a typical section selected from Pautût (figs 1,3), both vertically and laterally, and its sedimentological characters are discussed and a tentative depositional environment is presented.

\section{General geological setting}

The Atane Formation, which consists mainly of loose to weakly consolidated sediments, is found in the Nûgssuaq embayment of the West Greenland sedimentary basin which extends from Grønne Ejland and Disko in the south to Svartenhuk Halvø in the north. A thick sequence of marine and non-marine deposits was laid down (Rosenkrantz \& Pulvertaft, 1969) between the Early Cretaceous and the Danian. In Danian times the area was influenced by volcanism and the sediments in

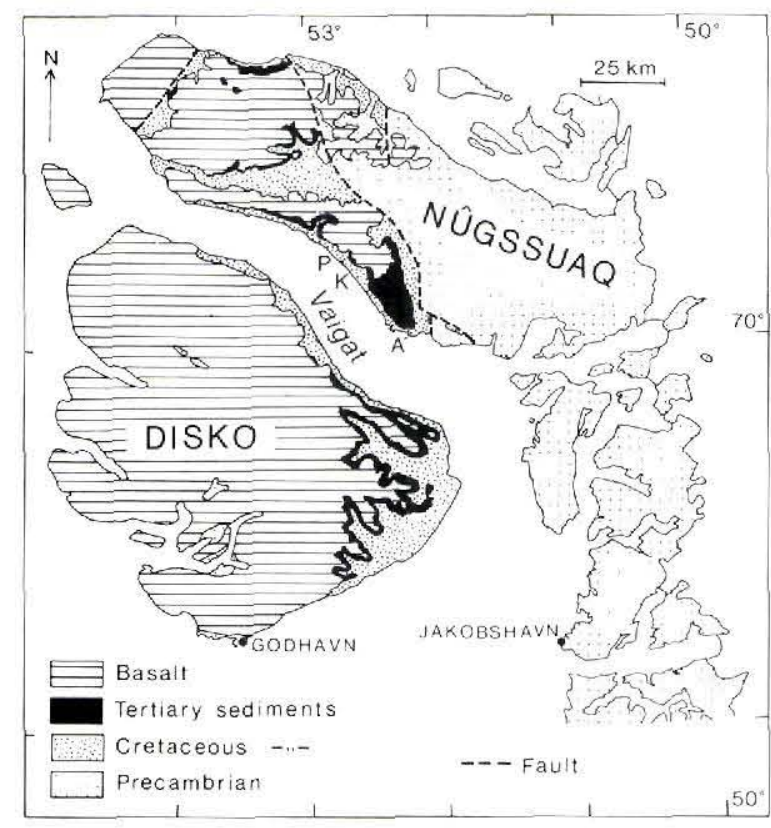

Fig. 1. Geological sketch map of Nûgssuaq and Disko indicating localities mentioned in the text. P: Pautût, K: Kingigtoq, A: Atanikerdluk. 

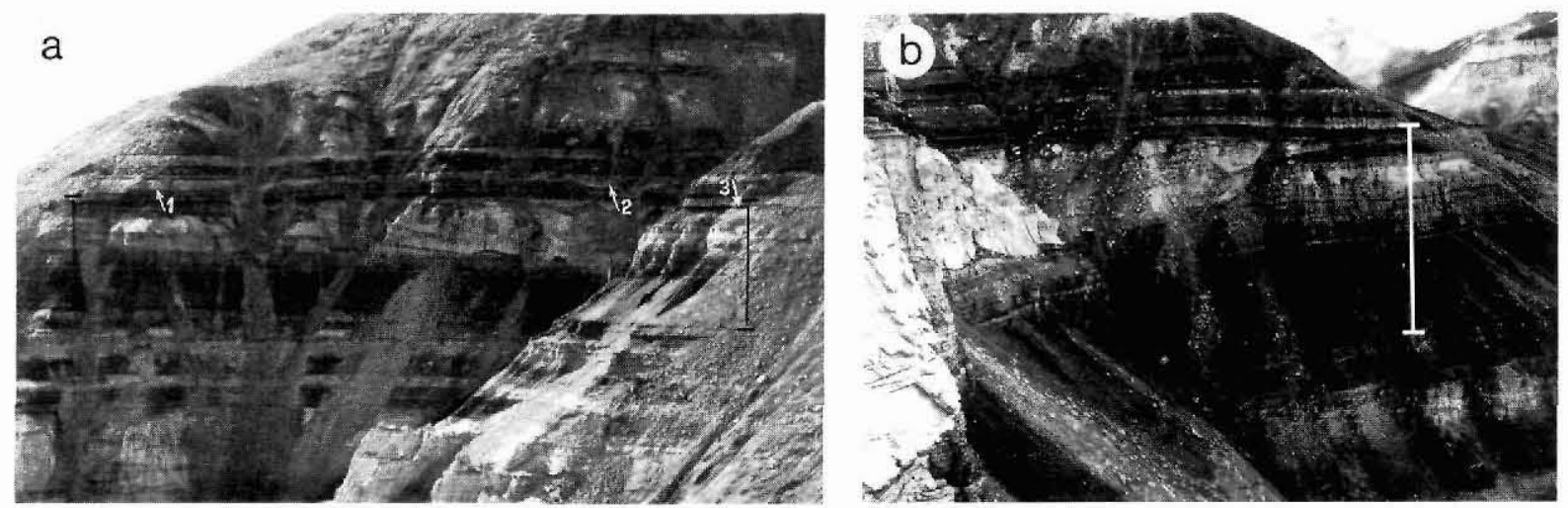

Fig. $2 a$. The section (c. $100 \mathrm{~m}$ long and $25 \mathrm{~m}$ high) seen from SE showing the top of the $3 \operatorname{logs}$ marked 1,2 and $3 . b$. The section indicating the position of $\log 3$ seen from the top of $\log 1$ (position 1 on fig. 2a). Note the increase in thickness and density of the sand-layers in the interdistributary bay shale association and the interdistributary bay sand association.

southern Nûgssuaq were covered by a thick series of basalt flows and agglomerates (Clarke \& Pedersen, 1976).

The Atane Formation was named by Heer (1883) who divided the sediments on the basis of plant macrofossils. The age, however, has remained uncertain but is generally considered to be Upper Cretaceous.

In southern Nûgssuaq the most striking feature of the Atane Formation is the stack of coarsening-upward sequences. One of these is the subject of this paper.

\section{Approach}

For a number of years geologists have relied heavily on one-dimensional sedimentological logs in the description of ancient sedimentary rocks. However, in the past decade emphasis has shifted towards a multi-dimensional approach, especially to fluvial and aeolian sediments (Friend et al., 1979; Allen, 1983; Miall, 1985). These papers have shown two-dimensional profiles, thus making use of the exposures as they are found. On the basis of profiles the internal build-up is deduced and, for fluvial sediments, is termed the fluvial architecture. This can be used to interpret the depositional environment and to classify ancient fluvial deposits.

The degree and size of exposure in the Atane Formation is adequate for detailed investigation of the spatial relations on a variety of scales. As part of the GGU coal project a total of approximately $12 \mathrm{~km}$ of sedimentological logs were measured during the summers of 1979 and 1980 of which a large part is from the Pautût area (Shekhar et al., 1982). Our interest was therefore focused on how best to use these logs together with our own in the interpretation of vertical and lateral changes in these stratified exposures. We tried to establish whether the need for a more precise description of lateral changes justifies the time-consuming and somewhat selective multi-dimensional analysis.

The selected section (fig. 2) serves to illustrate this problem. It is a typical although thick coarsening-upward sequence from the main valley of Pautût (fig. 3; Koch, 1959); both below and above the section similar sequences can be found.



Fig. 3. Oblique aerial photograph (route 514-G-N, Geodætisk Institut copyright) of the Pautût area. Position of section indicated by arrow. 

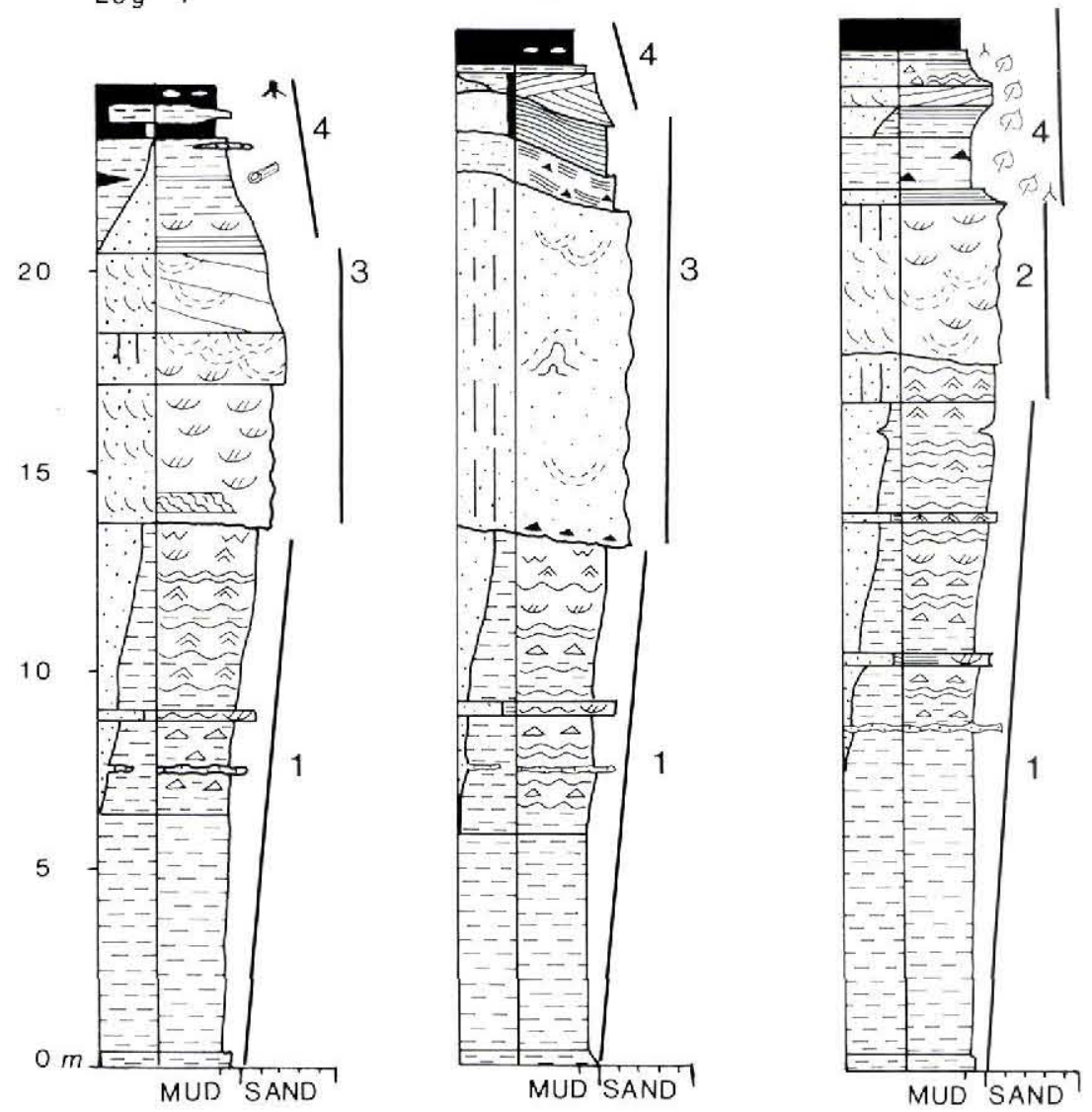

LEGEND

LITHOLOGY

$=$ mud

$\therefore$ sand

coal

- coalball (calcified)

11 cemented sandstone

(1) coaldrapes

SEDIMENTARY STRUCTURES

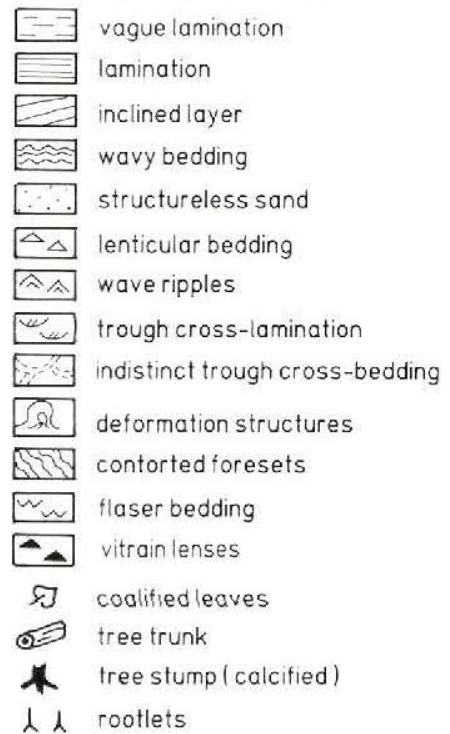

Fig. 4. Three measured logs through the section (fig. 2a for location). The four associations are indicated: 1 . Interdistributary bay shale association, 2. Interdistributary bay sand association, 3. Channel association, 4. Overbank association.

\section{Observations}

Vertical sequence. Three logs (fig. 4) were measured through the selected section (fig. 2). In the logs four different sedimentary associations are recognised. They will be described here and an interpretation made in the depositional history part.

Interdistributary bay shale association. The lowest part of this association is a layer up to $0.5 \mathrm{~m}$ thick of black laminated fissile shale with a high content of sand-size coal fragments. Overlying this a dark grey shale with an irregular fissility is found. Due to this fissility no internal structures are observed. Knobbly elliptical concretions $1-2 \mathrm{~cm}$ thick form discontinuous layers.

At the top the shale is gradually succeeded by stringers and thin lenses of very fine sand, leading to a heterolithic sediment. The sand layers become thicker upwards, beginning with laminae thinner than $1 \mathrm{~mm}$ of very fine sand. At the top of the association there are about $2 / 3$ of very fine sand and $1 / 3$ of silt. The sedimentary structures change from plane lamination to lenticular and wavy bedding. At the top, wave-produced ripples and flaser bedding are found, flasers being composed of silt with a high organic (coal) content.

In two horizons, at about $8.5 \mathrm{~m}$ and $10 \mathrm{~m}$ on the $\operatorname{logs}$ (fig. 4), two layers of almost pure sand are found. The first layer is apparently massive, whereas the other displays wave-generated ripple lamination. No fossils are found except for rare trace-fossils, and the structures in the heterolithic sediment are well preserved. Small sand-filled cracks $1-3 \mathrm{~mm}$ wide and up to $1 \mathrm{~cm}$ deep are frequently seen in the silty parts. The silt laminae become increasingly enriched in coal fragments, turn darker and show stronger fissility passing upwards in the sequence.

Interdistributary bay sand association. There is a gradual transition from the interdistributary bay shale association into this association of well sorted fine quartz 


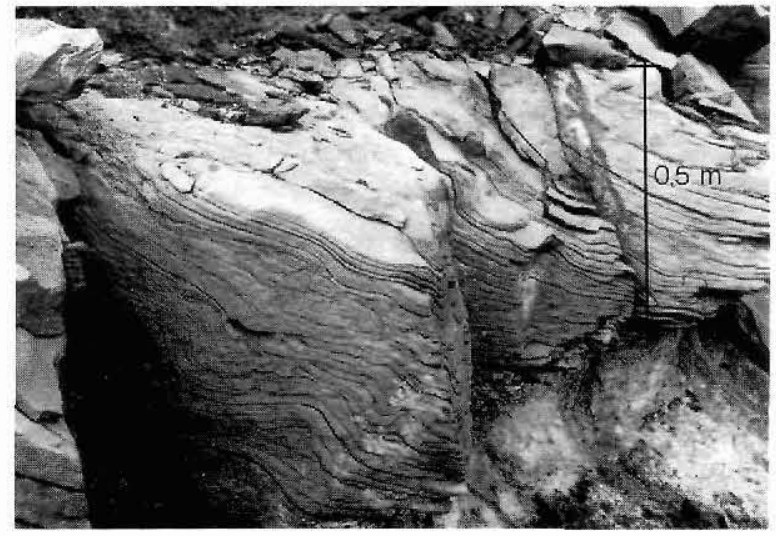

Fig. 5. Large scale cross bedded set from the channel association showing deformed foresets.

sand. Sand-size coal fragments are often found in laminae less than $1 \mathrm{~mm}$ thick draping the foresets. Smallscale trough cross-bedding is the dominant sedimentary structure, but also isolated large-scale trough cross-bedded sets, typically $30-50 \mathrm{~cm}$ thick, are seen. Flasers and wave-generated ripples are abundant in the lower part of this association.

Channel association. The base of this association is erosive and the otherwise indistinct channel lag deposit contains scattered pebble-size coal fragments. The association is generally composed of poorly sorted medium sand, with the grain size varying from very fine to coarse. Some parts of the sand are cemented and sedimentary structures are often hard to recognise. When found, they usually consist of large-scale cross-bedding showing rather uniform current directions from bed to bed, and with set heights varying from $0.1 \mathrm{~m}$ up to $3 \mathrm{~m}$.

In this particular section only a few examples of indistinct large-scale trough cross-bedding and some deformed large-scale structures are seen, with organic material marking the foreset laminae. In a single bed $50 \mathrm{~cm}$ thick a large-scale cross-bedded set with foresets contorted into folds is found (fig. 5).

Overbank association. This association contains a variety of $0.2-2 \mathrm{~m}$ thick horizontal to gently dipping beds of very fine sand, silt, clay and coal, which generally constitute a fining-upward sequence. Typical features are, however, the mixing of lithologies and the poorly developed sedimentary structures. The sand occurs in laminated beds, where laminae less than $1 \mathrm{~cm}$ are interbedded with black silty sand containing much coalified plant debris. Sand is also found as laminae and lenses interbedded with silt thus making up a heterolithic sediment. Here it is often possible to recognise roots, whereas this is seldom possible in the silt and clay, due to the colour and fissility. In the siltstone no internal structures, except for some irregular horizontal stratification marked by leaves and organic debris, can be seen in outcrop. Occasionally $1-2 \mathrm{~cm}$ thick lenses of vitrain coal are found together with rootlets, tree trunks and coalified leaves. Sand size coal fragments are also abundant.

The association is usually capped by a coal layer. The coal is mainly vitrain and clarain (Shekhar et al., 1982), sometimes interbedded with discontinuous silt layers and lenses. Carbonate 'coalball' concretions $30-40 \mathrm{~cm}$ thick occur within the coal and often tree trunks 'on the stump' are seen inside these coalballs.

Lateral variation. The three logs shown in fig. 4 demonstrate that lateral changes do occur within a relatively short distance (appproximately $100 \mathrm{~m}$ ).

The top and bottom parts of the section are, however, similar on all three logs and their correlation can be seen in fig. 6, drawn on the basis of fig. 2 and other photographs, field notes and the logs. It is seen that the basal part of the section is laterally consistent within the area shown. From field work at Pautût, this particular interdistributary bay shale sequence is known to cover a very large area, displaying only minor changes in thickness and internal order. The two sand layers at 8.5 and $10 \mathrm{~m}$ (fig. 2) serve to characterise the sequence, thus making it one of the best marker horizons in the area.

The interdistributary bay sand association is found above the interdistributary bay shale association but is truncated by a lens shaped body of sand (figs 2,6). Here lithologies and sedimentary structures change rapidly. Low-angle lateral accretion surfaces, often relatively fine-grained, separate layers of sand with a number of different structures (fig. 5). More often, however, the primary structures are to some degree destroyed by water escape deformation structures.

Intercalated with, and above the channel sediments, finer grained deposits belonging to the overbank association occur. The lateral continuity varies from small lenses of silt and very fine sand to coal layers kilometres wide. These coal layers may constitute the top of the sequence (fig. 4) and have a thickness of up to $2 \mathrm{~m}$ (in one rare case $5 \mathrm{~m}$ ). In several sections, however, the coal seams are intercalated with clay containing lenses of coal and much organic debris. The coal layers vary in thickness as seen on the profile and the lateral continuity is generally less than the interdistributary bay shale association. 


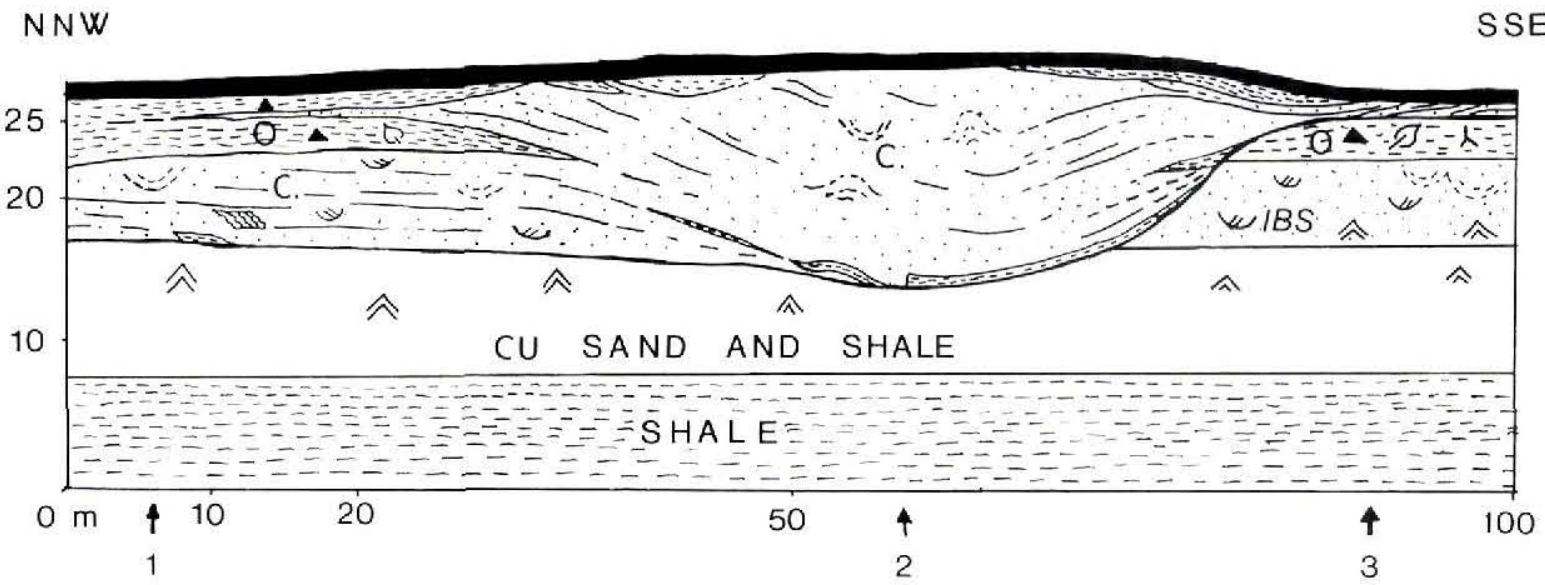

Fig. 6. Constructed profile of the section. Note the lateral continuity of the interdistributary bay shale association and the topmost coal seam. The channel association constitutes a single storey sand body, that is deposited from only one channel. The very distinct erosive contact to the underlying associations is also noted (legend see fig. 4), O denotes overbank association, $\mathrm{C}$ channel association and IBS interdistributary bay sand association. The positions of the vertical logs (fig. 4) are shown.

\section{Depositional history}

Due to the well developed coarsening-upward sequence, the abundance of wave-generated structures, the occurrence of some trace fossils and marine macrofossils (Ravn, 1918) and the general deltaic association (Elliott, 1974, 1982), the two lower associations are thought to represent the infilling of an interdistributary bay. After the establishment of a marshy lower delta plain, overbank fines were deposited from suspended material only during major floods.

Later, the lower delta plain sediments were eroded by a distributary river system. On figs 2 and 6 it is seen that a distributary channel migrated to the right, by erosion on the right bank (cut bank), and at the same time sand and fine sediments were deposited by lateral accretion on the left bank where the layers follow the slope of the point-bar. The channel can be followed through successive gullies and is seen to have a direction towards the NNE in accordance with the overall transport direction that was from south to north (Shekhar et al., 1982). During low flow stages silt was deposited on the pointbar and only during floods could the intercalating sand layers be deposited (Reineck \& Singh, 1973). Crossbedding with deformed foresets (fig. 5) are found in the sand layers, which indicates that the sand was probably deposited very quickly (Reineck \& Singh, 1973). Thus each sand layer may represent one flood event. Due to the sedimentary structures and especially the geometry (fig. 6) this association is recognised as a channel-fill and is termed accordingly.

The infilling of the channel is thought to have occurred rapidly because of the rather massive appearance of the sand in places, the abundance of sediment deformation structures and the almost entirely sandy sediment. The very last infilling of sand may have happened while the entire flood plain was flooded, thus depositing sand and silt over a wide area. On figs $2 \mathrm{~b}$ and 6 it is seen that this layer extends over the silty flood plain sediments.

After the infilling of the channel the area received only limited amounts of fine clastic material and gradually became covered by vegetation, as indicated by a number of small roots in the underlying sediments and calcified tree stumps in situ. The accumulation of peat has been the source of this major coal layer.

Differentiated compaction has resulted in the convex shape of the sandy channel fill, because the silty and clayey sediments originally had a much higher porosity than the sand.

\section{Conclusions}

The present investigation has indicated that considerable lateral variation may exist within sandstone bodies (channel association) and within overbank deposits (overbank association) which appear to be laterally continuous and uniform when viewed from a distance. It has also been seen that the need for two-dimensional profiles and three-dimensional models is confined to these associations, while the basal interdistributary bay shale and, to a somewhat lesser degree, the interdistributary bay sand association are characterised by marked lateral continuity. 
Acknowlegdements. We thank GGU for financial and logistic support, Feiko Kalsbeek (GGU) for his efforts in never declining our wishes while in the field, and our supervisor Gunver Karup Pedersen (University of Copenhagen), Ole Bang Berthelsen (University of Copenhagen) did the photographic work and Chris Pulvertaft (GGU) critically read this note and kindly improved the English.

\section{References}

Allen, J. R. L. 1983: Studies in fluviatile sedimentation: bars, bar-complexes and sandstone sheets (low sinuosity braided streams) in the Brownstones (L. Devonian), Welsh Borders. Sediment. Geol. 3, 237-293.

Clarke, D. B. \& Pedersen, A. K. 1976: Tertiary volcanic province of West Greenland. In Escher, A. \& Watt, W. S. (edit.) Geology of Greenland, 368-385. Copenhagen: Geol. Surv. Greenland.

Elliott, T. 1974: Interdistributary bay sequences and their genesis. Sedimentology 21, 611-622.

Elliott, T. 1982: Deltas. In Reading, H. G. (edit.) Sedimentary facies and environments, 113-154. Oxford: Blackwell.

Friend, P. F., Slater, M. J. \& Williams, R. C. 1979: Vertical and lateral building of river sandstone bodies, Ebro Basin, Spain. J. geol. Soc. Lond. 136, 39-46.

Henderson, G., Rosenkrantz, A. \& Schiener, E. J. 1976: Cretaceous-Tertiary sedimentary rocks of West Greenland. In Escher, A. \& Watt, W. S. (edit.) Geology of Greenland, 340-362. Copenhagen: Geol. Surv. Greenland.

Heer, O. 1883: Oversigt over Grønlands fossile flora. Meddr Grønland 5, 79-202.

Kalsbeek, F. 1989: GGU's expedition in the Disko Bugt area. Rapp. Grønlands geol. Unders. 145 (this volume).

Koch, B. E. 1959: Contributions to the stratigraphy of the non-marine Tertiary deposits on the south coast of the Nûgssuaq Peninsula, Northwest Greenland. Bull. Grønlands geol. Unders. 22 (also Meddr Grønland 162,1), 53 pp.
Miall, A. D. 1985: Achitectural-element analysis: a new method of facies analysis applied to fluvial deposits. EarthSci. Rev. 22, 497-505.

Miall, A. D. 1988: Architectural elements and bounding surfaces in fluvial deposits: anatomy of the Kayenta Formation (Lower Jurassic), Southwest Colorado. Sediment. Geol. 55, 233-262.

Ravn, J. P. J. 1918: De marine Kridtaflejringer i Vest-Grønland og deres Fauna. Meddr Grønland 56, 309-380.

Reineck, H. E. \& Singh, I. B. 1973: Depositional sedimentary environments - with reference to terrigenous clastics, $439 \mathrm{pp}$. Berlin: Springer Verlag.

Rosenkrantz, A. 1970: Marine Upper Cretaceous and lowermost Tertiary deposits in West Greenland. Meddr dansk geol. Foren. 19, 406-453.

Rosenkrantz, A. \& Pulvertaft, T. C. R. 1969: CretaceousTertiary stratigraphy and tectonics in northern West Greenland. Mem. Am. Ass. Petrol. Geol. 12, 883-898.

Schiener, E. J. 1975: Basin study: central West Greenland onshore Cretaceous-Tertiary sediments. 9 th int. Congr. Sedimentology 5(2), 379-385.

Seward, A. C. 1926: The Cretaceous plant-bearing rocks of western Greenland. Phil. Trans. roy. Soc. London B, 215, 57-175.

Shekhar, S. C., Frandsen, N. \& Thomsen, E. 1982: Coal on Nûgssuaq, West Greenland, 82 pp. Copenhagen: Geol. Surv. Greenland.

Steenstrup, K. J. V. 1874: Om de kulförende Dannelser paa Öen Disko, Hareöen og syd-Siden af Nugssuak's Halvöen i Nord-Grönland. Vidensk. Meddr dansk naturh. Foren. 1874, 76-112.

H. M. \& T. O. Institut for Almen Geologi, Oster Voldgade 10, DK-1350 København K, Danmark.



\title{
New observations of marine trace fossils in delta plain sequences, southern Nûgssuaq, West Greenland
}

\author{
Gunver Krarup Pedersen and Birgitte Ferré Rasmussen
}

During the 1988 field season new observations were made on the sediments of the Upper Cretaceous Atane Formation in southern Nûgssuaq. These observations indicate that the degree of bioturbation may be taken as an indicator of the degree of marine influence within the interdistributary delta plain environments. The field work was carried out during six days in July 1988 as part of a sedimentological research project supported by

\section{GGU and the Danish Natural Science Research Coun-} cil.

\section{Background}

Impressive sections of Cretaceous deltaic deposits are exposed along the southern coast of Nûgssuaq and in the Auvfarssuaq valley (fig. 1). The Cretaceous deposits 